\title{
Measurement of environmental warmth in SI units
}

\author{
F. P. ELLIS, ${ }^{1}$ F. E. SMITH, ${ }^{2}$ and J. D. WALTERS \\ John B. Pierce Foundation Laboratory and Yale University School of Medicine ; \\ Medical Research Council Headquarters Staff; and Institute of Naval Medicine, Alverstoke
}

\begin{abstract}
Ellis, F. P., Smith, F. E., and Walters, J. D. (1972). Brit. J. industr. Med., 29, 361-377. Measurement of environmental warmth in SI units. Although 'Environmental Warmth and Its Measurement' (Medical Research Council War Memorandum No. 17), written over 25 years ago for the Royal Navy, is still widely used and has not been revised, the validation and amplification of the methods proposed by the late Dr. Thomas Bedford have in the meantime been in hand continuously in the laboratory and in the Fleet under the auspices of the Council's Royal Naval Personnel Research Committee. While it was not considered appropriate by Council to replace or to rewrite the Memorandum at the present time, in view of the recent adoption of the metric system and the units of the International System (SI Units) it was thought that it would be helpful to publish metricated charts corresponding to those which appear in the Supplement to War Memorandum No. 17, together with two additional charts which are the result of work in the post-war years, to provide investigators with simple aids for use in the laboratory or the field and to provide a basis for considering the requirements for further research.
\end{abstract}

\section{The present position}

'Environmental Warmth and Its Measurement', War Memorandum No. 17 of the Medical Research Council's Royal Naval Personnel Research Committee (RNPRC), was drafted in 1944 by the late Dr. Thomas Bedford. He revised it in 1945 after trials in the Eastern Fleet in the latter half of 1944 (Ellis, 1945, 1947a and b, 1948) and it was published by His Majesty's Stationery Office in 1946. The

\footnotetext{
'Present address: Royal Navy, Royal Marines and WRNS Careers Headquarters, West Midland Region, Unit 46, Birmingham Shopping Centre, Birmingham B2 4XD.

${ }^{2}$ Present address: Mayfield, 4 Hawthorn Way, Sonning-onThames, Berkshire RG4 OTG.

Requests for reprints to Secretary, Royal Naval Personnel Research Committee, Room 1518, Ministry of Defence (Navy), Empress State Building, Lillie Road, London, SW6 1TR.
}

methods outlined were still recommended 20 years later by Bedford (1964) in the second edition of his book Basic Principles of Ventilation and Heating. The first draft was prepared for the guidance of naval medical and engineer officers and ship constructors who had the task of measuring the thermal environment between decks and in machinery spaces in the tropics and subtropics in 1944 under action and cruising conditions. These measurements provided a framework for laboratory investigations at the Medical Research Council's Hot-climate Research Unit at the National Hospital, Queen Square, London and the Council's Applied Psychology Research Unit, Cambridge, and later at the Royal Naval Tropical Research Unit, Singapore, which were designed to determine the levels of warmth at which the efficient performance of different kinds of work vital to the fighting efficiency of the Fleet was likely to be impaired. 
Laboratory research and field studies afloat and on shore added considerably to the knowledge available during the second world war. New methods were developed for assessing the relative severity of different combinations of the main thermal factors involved under widely different working conditions and at different levels of warmth, and in some respects, though by no means all, these new methods are preferable to those recommended by Bedford when used for the specific purposes for which they were devised. Electrical instruments are now available and are well tested, enabling the various measurements to be made more speedily and conveniently than hitherto (Walters, 1967).

In 1966 one of us (F.P.E.) was invited by the Medical Research Council to undertake the revision or replacement of 'Environmental Warmth and Its Measurement' and a Climatic Factors Subcommittee of the RNPRC was appointed to sponsor the revision and advise the Navy on other problems of a climatic nature. After consultation with workers in Britain, the United States of America, Australia, and South Africa, it was decided in July 1968 that the first step should be the preparation of an account of the work which had been carried out for the RNPRC on the measurement of environmental warmth and its effects since 1944. The first account (Ellis, 1969) was written for the Ninth Commonwealth Defence Conference on Clothing and General Stores and was then rewritten for the RNPRC's Subcommittee on Environment (Ellis, 1969, 1970). In the meantime the need for further research in this general area was also emphasized by a Scientific Group of the World Health Organization (1969).

In the light of these various discussions the Medical Research Council decided in January 1971 that the rewriting or replacement of War Memorandum No. 17 would be premature despite the lapse of time since the War Memorandum was published and the various limitations of the methods recommended by Bedford, particularly their time-consuming nature when carried out precisely as he prescribed. Pending a re-evaluation of the old and new methods of measurement for the RNPRC Subcommittee on Environment a reprinting of War Memorandum No. 17 and its supplemental charts with imperial units was recommended to cover requirements for the next five years.

\section{Metrication of charts for the measurement of environmental warmth}

The events which preceded the acceptance of the Système Internationale, or the International System, units by the British Government are summarized in the recent White Paper (1972). Although the new system departs in some respects from the previous version of the metric system used in Britain, the metre, gramme, litre, and watt and their multiples and submultiples, which are used in the measurement of environmental warmth and its effects on man, are practically the same in both systems. A comprehensive description is provided by the National Physical Laboratory (1970) and a simplified account by the Metrication Board (1970). Publications by the British Standards Institution $(1959,1962,1967)$ and Anderton and Bigg (1969) contain conversion factors and tables, and there are two publications by the Royal Society $(1968,1969)$ on metrication in scientific journals and on the symbols, signs, and abbreviations recommended for British scientific publications respectively.

When the decision was made to defer for the time being the publication of another memorandum on environmental warmth and its measurement one of us (F.P.E.) was requested by the Medical Research Council to arrange for the publication of metricated versions of the Charts in the Supplement to War Memorandum No. 17 and of additional charts produced in the last quarter of a century for the RNPRC to facilitate the transition from the use of imperial to metric units at the working level during the 1970s. A first attempt at this had been made by two of us (F.P.E. and J.D.W.), with the assistance of the third (F.E.S.) who, with Mr. (now Dr.) F. A. Chrenko, drew the originals of the charts under Bedford's direction in 1944 and 1945. These metricated versions are reproduced here as Charts 1 to 9. Experience over the years has shown that considerable care is necessary in their interpretation and use.

It has been established that the effective temperature charts, for example, are misleading when used to predict physiological effects at levels of warmth verging on those at which heat collapse may occur (Ellis, Ferres, Lind, and Newling, 1953), that is to say at effective temperatures above $32.2^{\circ} \mathrm{C}$ $\left(90^{\circ} \mathrm{F}\right)$ for trained acclimatized young men doing moderate work in light clothing for periods not exceeding 4 hours. This limiting level of warmth would be appreciably lower for untrained unacclimatized young men and probably for older or younger persons. These scales were devised and should be used only for assessing the effects of warmth on persons engaged in sedentary or very light work wearing either light indoor clothing (the 'Normal' Chart, Chart 9) or stripped to the waist (the 'Basic' Chart, Chart 8). Re-using the data of the Medical Research Council's wartime experiments at the National Hospital, Queen Square, one of us (F.E.S.) showed that, if the sweat rate is used as an index of heat stress, the rate at which a man works can be taken into account with effective temperature either by the addition of a simple supplementary nomogram or by the use of a series of graphs which are included in Medical Research Council Memorandum No. 29 


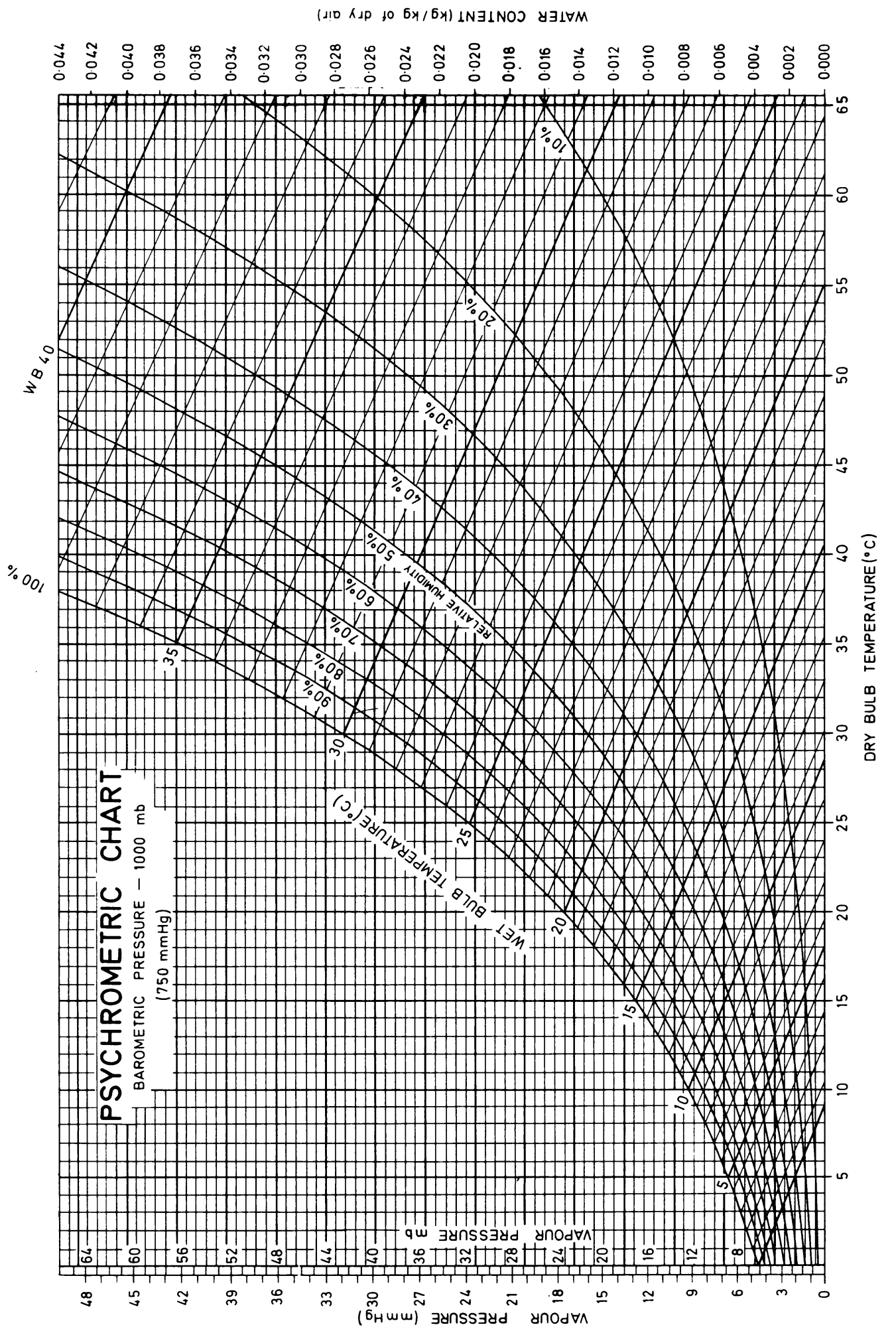

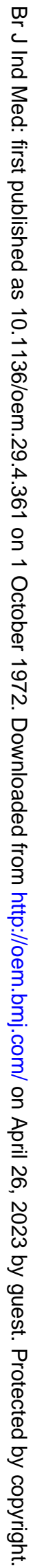




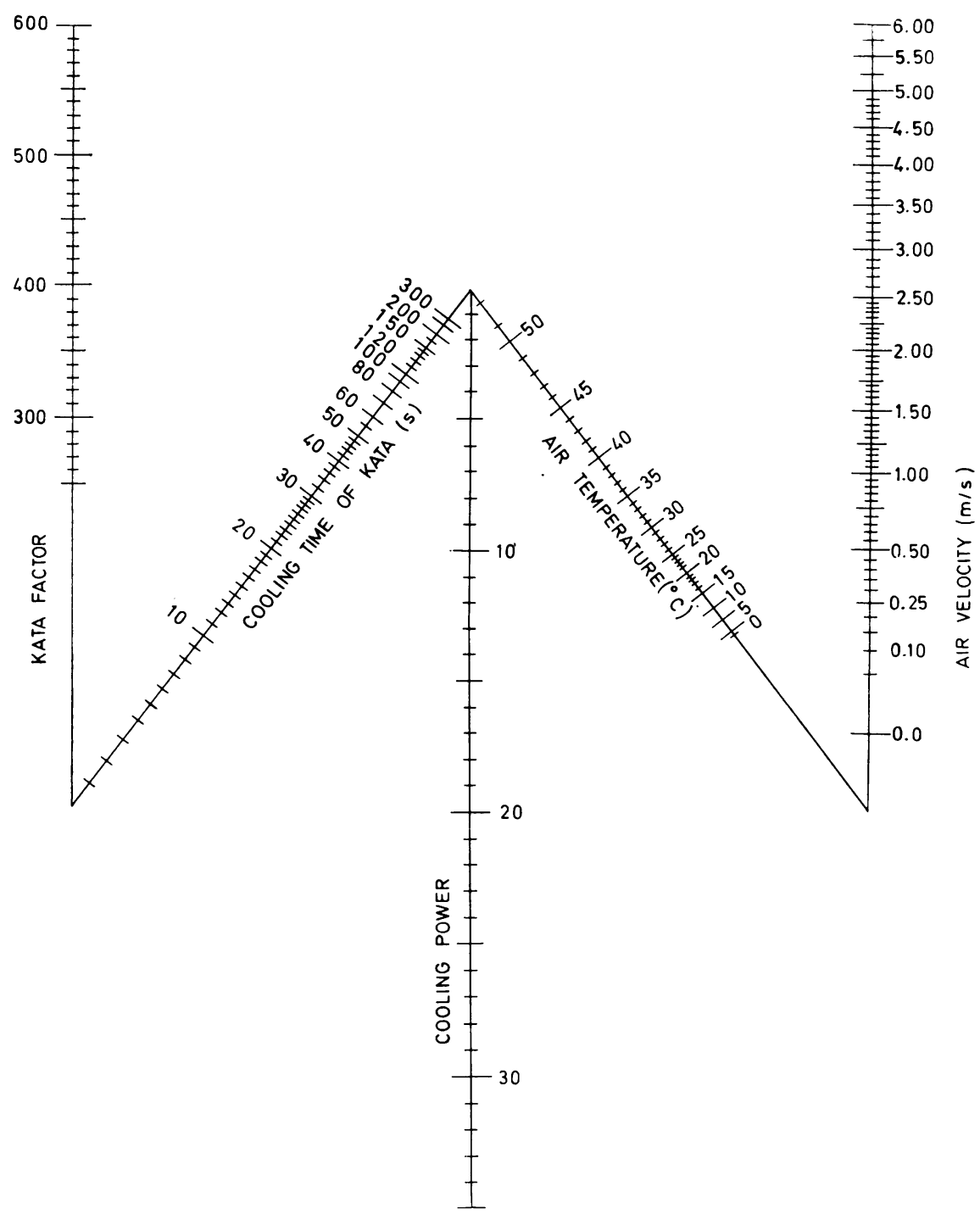

CHART 2. Chart for the computation of air velocities from readings of the silvered high temperature Kata thermometer, cooling range $54 \cdot 4-51 \cdot 7^{\circ} \mathrm{C}\left(130-125^{\circ} \mathrm{F}\right)$.

(Smith, 1952, 1955). We have, therefore, included as Chart 10 a 'beheaded' normal effective temperature chart, which excludes the physiologically misleading sector of the old chart and, for certain levels of warmth where heat stress may be critical, is adjusted for work rate according to Smith's calculations.

We have also included as Chart 11 a metricated version of the Predicted 4-hour Sweat Rate Chart (McArdle et al., 1947). This empirical nomogram was constructed by McArdle after the Queen Square team had disbanded at the termination of hostilities by fitting the data of various wartime experiments to a series of curves shown on the nomogram. This nomogram provides a more reliable index of physiological effect than effective temperature for men working at tasks involving widely varying energy costs in thermal environments verging on the limits of what can be tolerated. Despite the comparative paucity of data derived from experiments which had not been conceived for this specific 


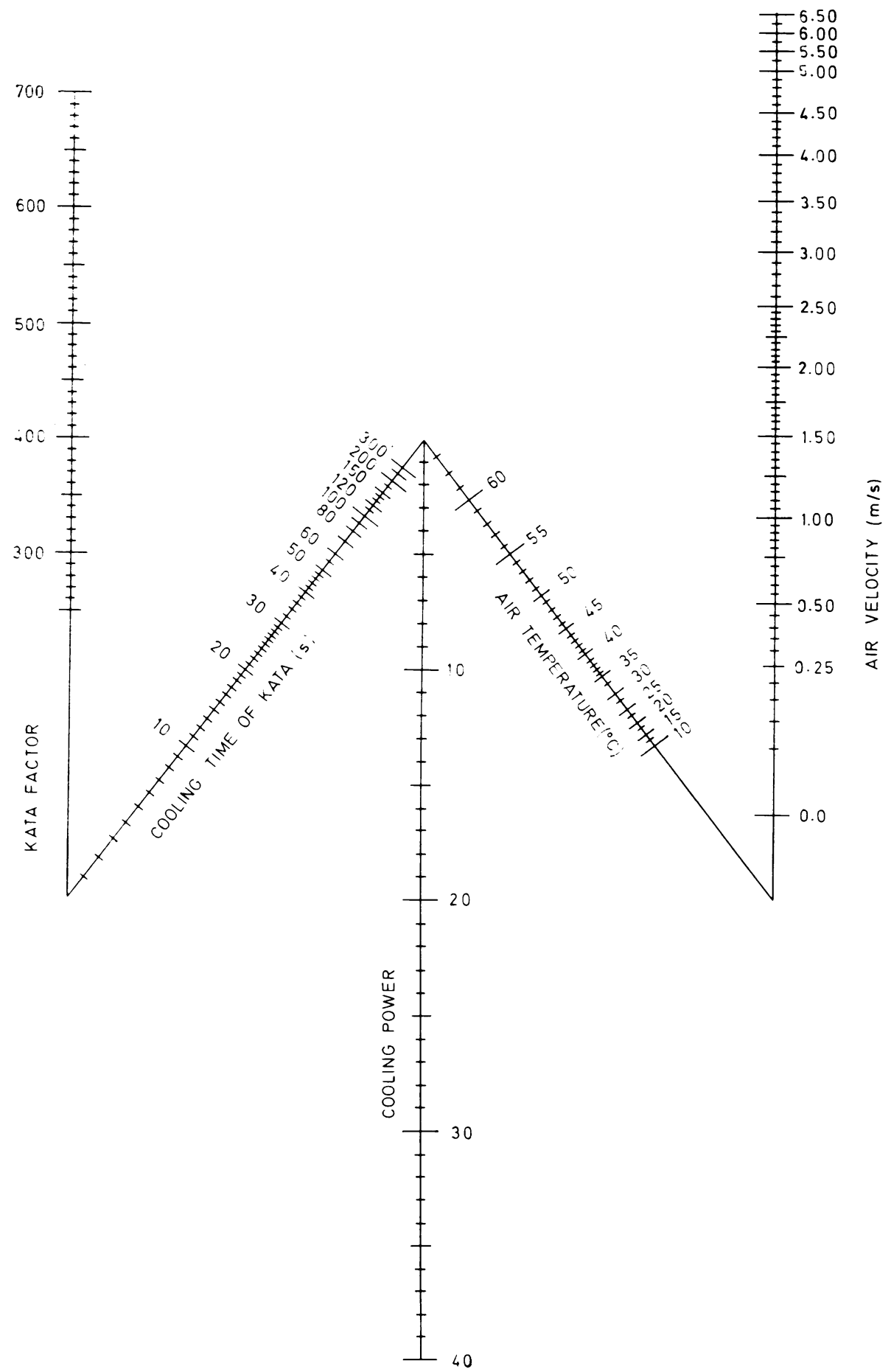

CHART 3. Chart for the computation of air velocities from readings of the silvered high temperature Kata thermometer, cooling range $65 \cdot 6-62 \cdot 8^{\circ} \mathrm{C}\left(150-145^{\circ} \mathrm{F}\right)$. 

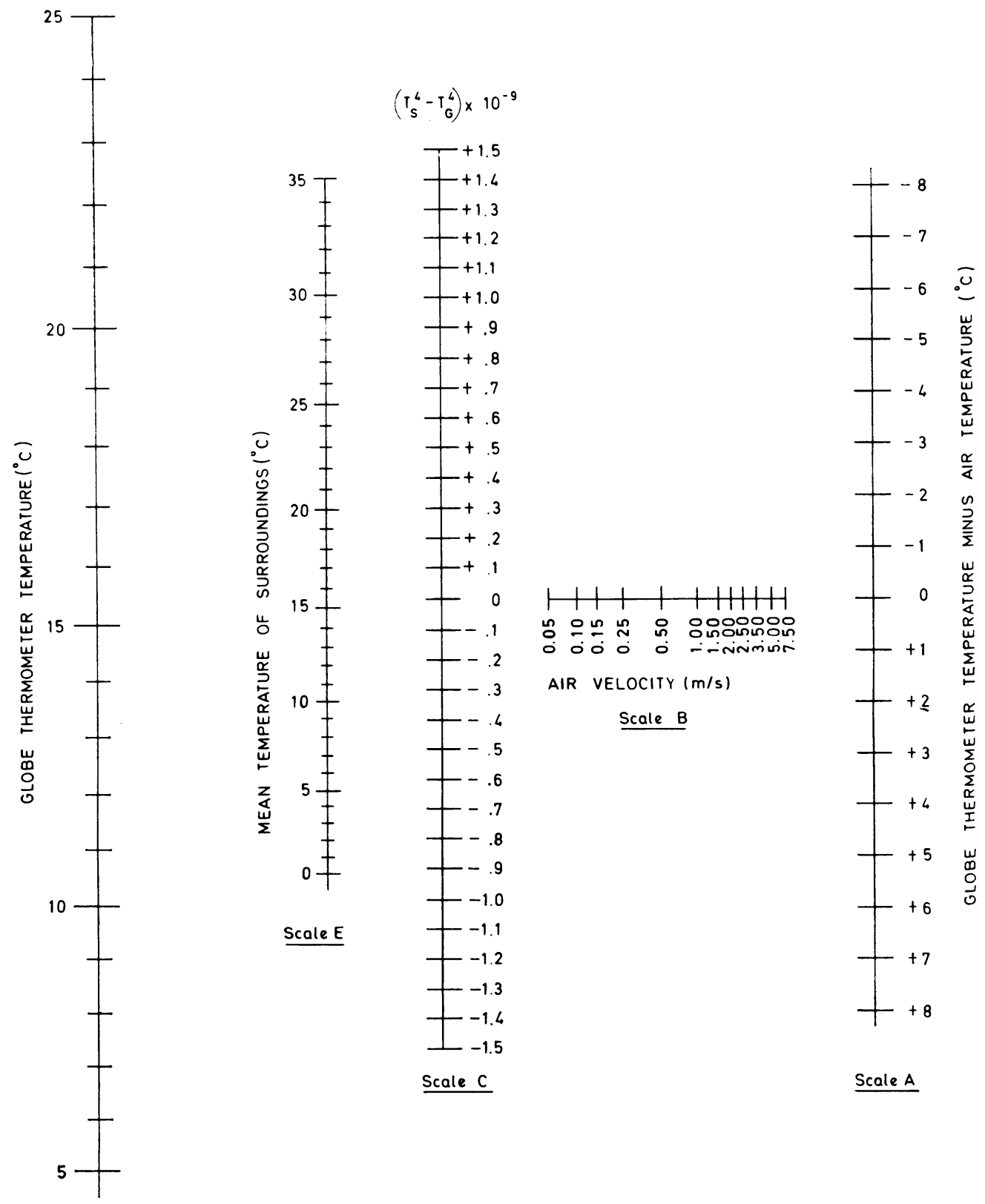

Scale C

Scale A

Scale D

CHART 4. Chart for the estimation of radiation from globe thermometer readings. 

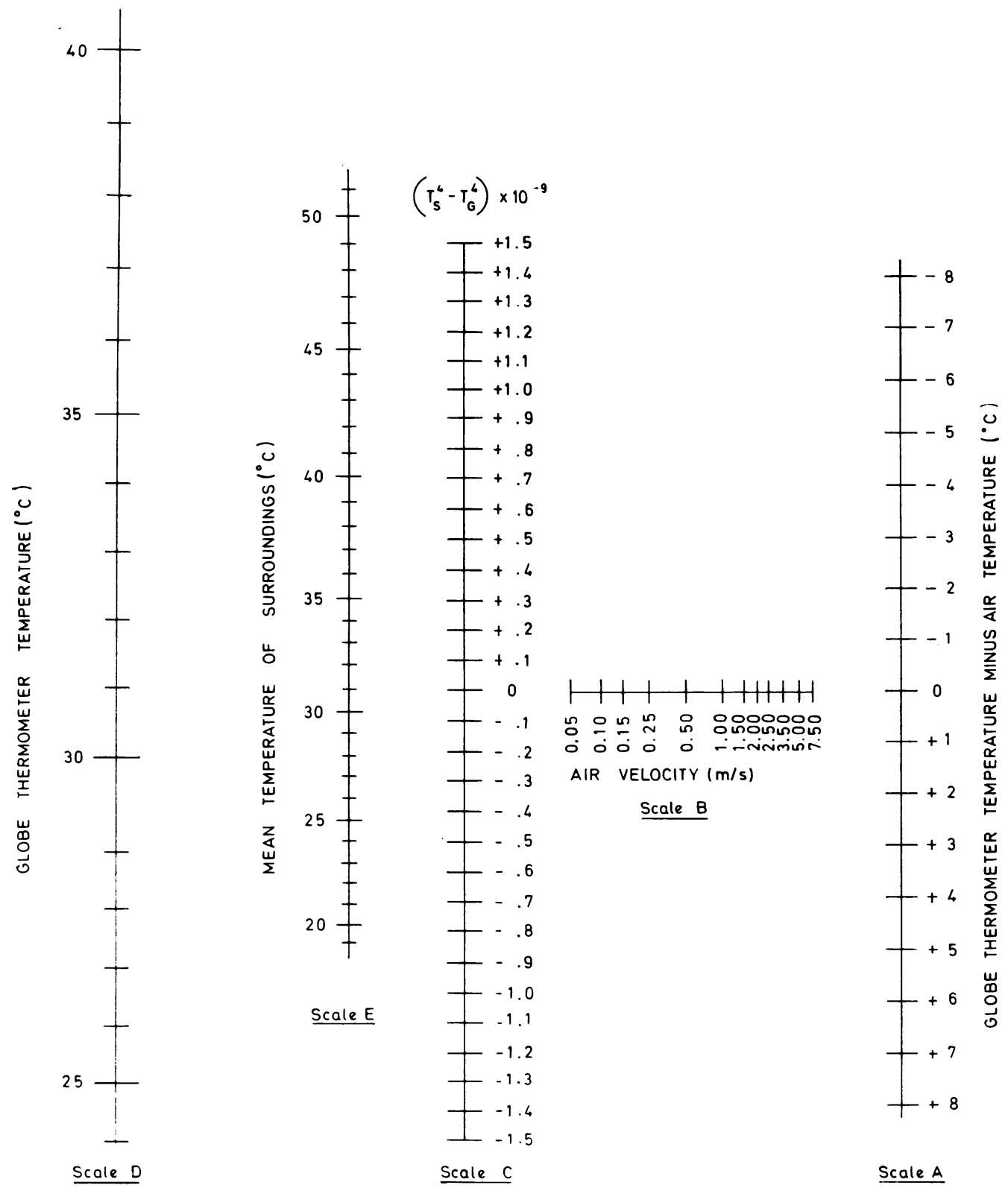

CHART 5. Chart for the estimation of radiation from globe thermometer readings. 

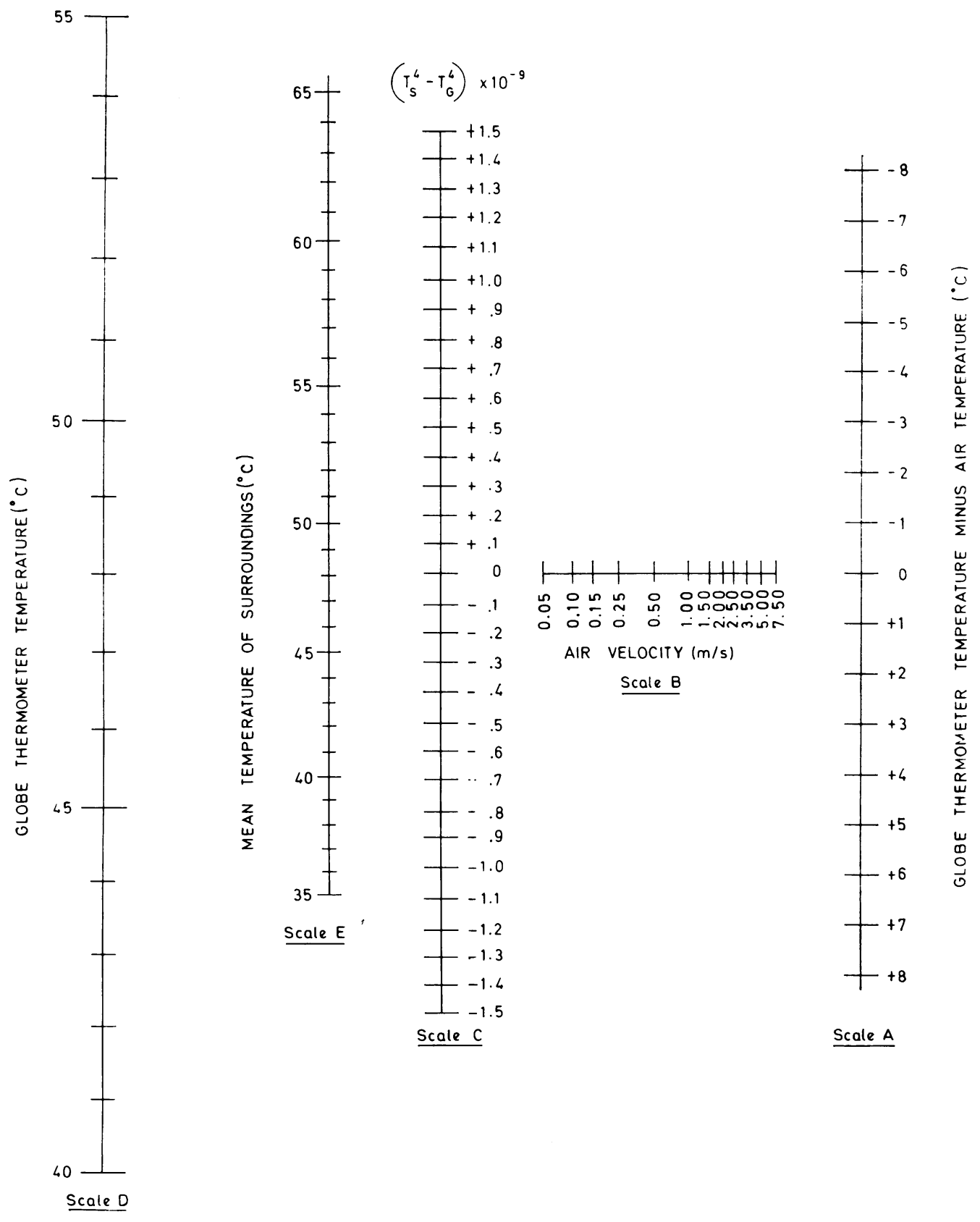

Scale A

CHART 6. Chart for the estimation of radiation from globe thermometer readings. 

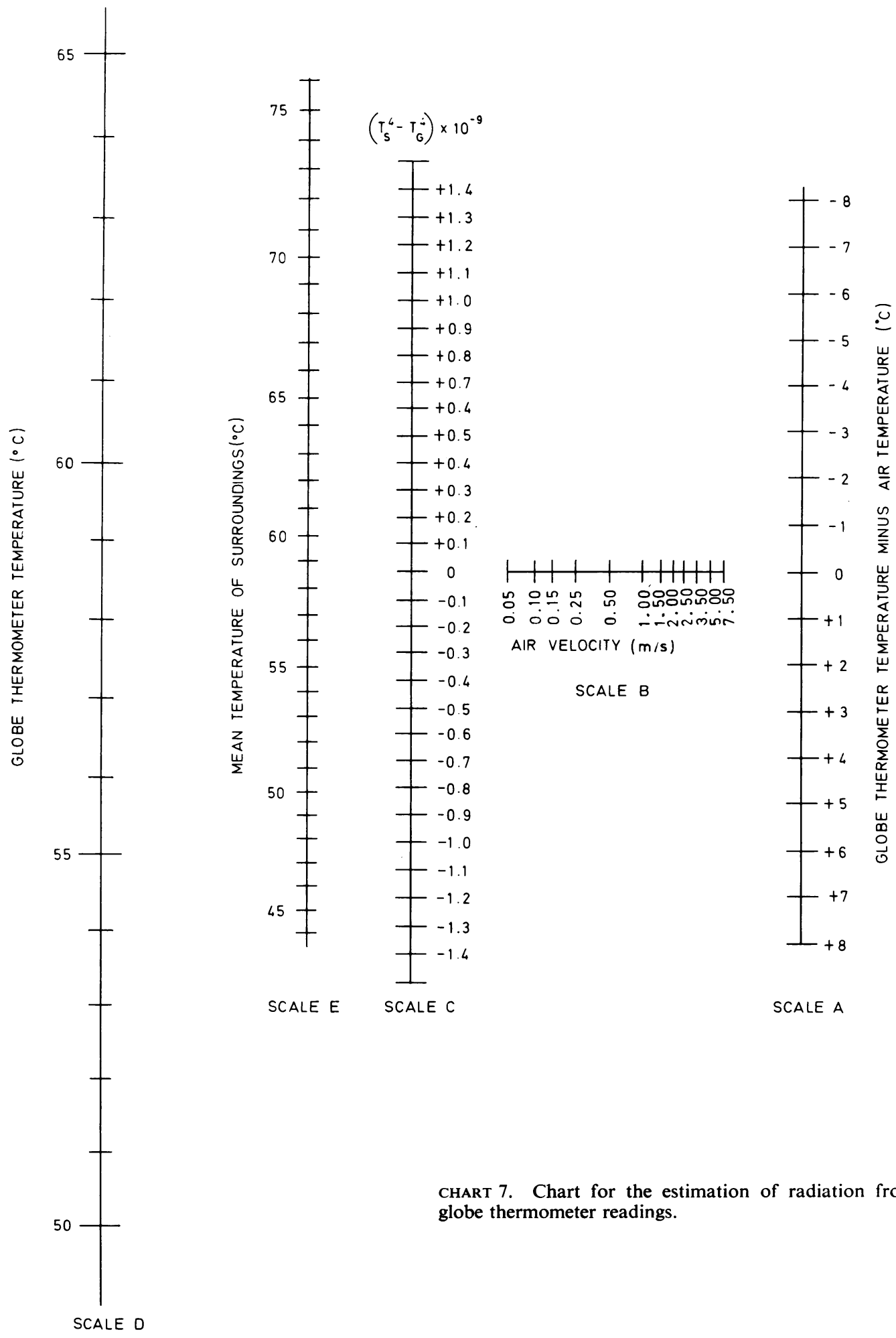

SCALE E

SCALE C

SCALE A

CHART 7. Chart for the estimation of radiation from globe thermometer readings. 


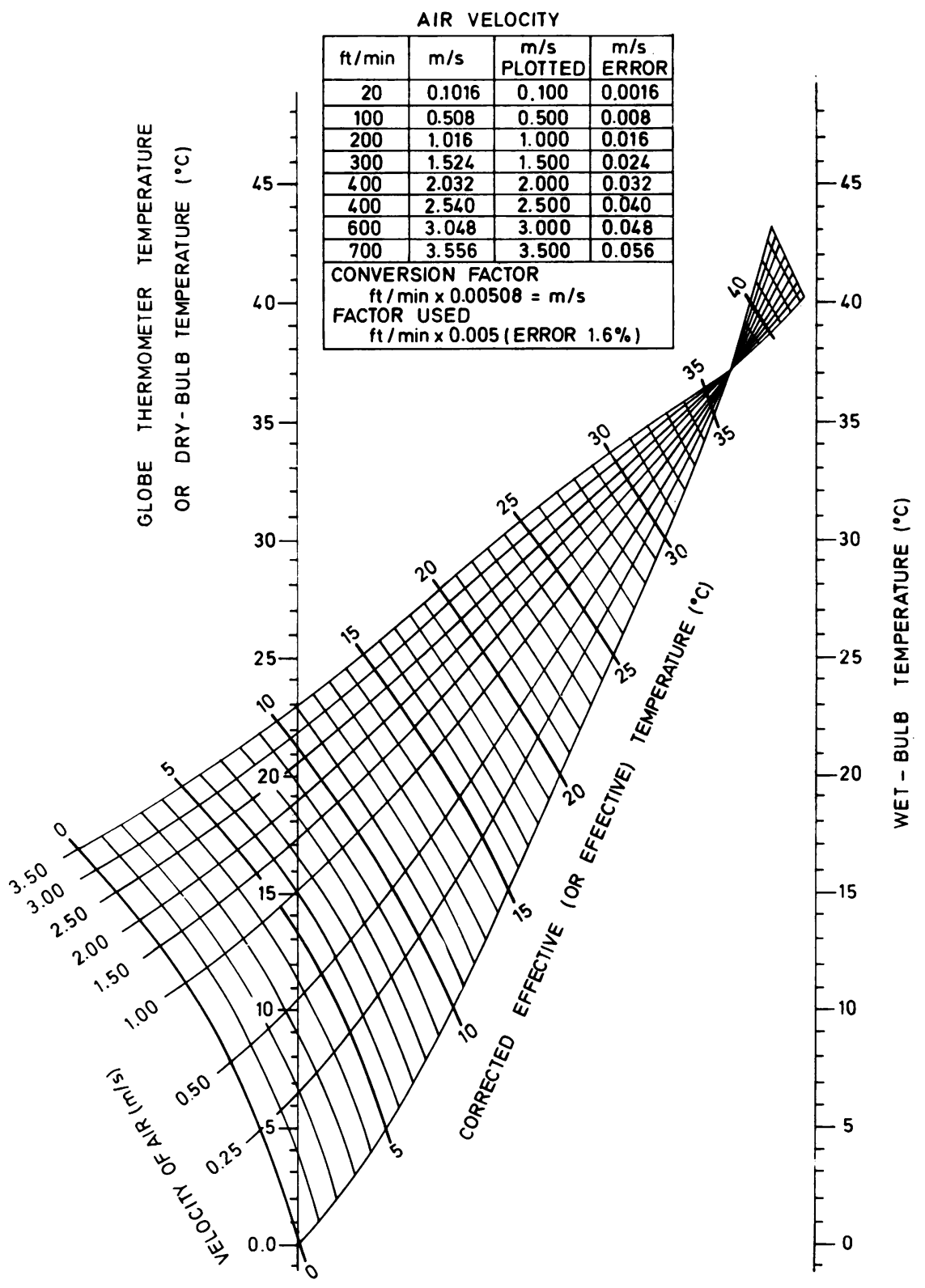

CHART 8. Chart showing basic scale of corrected effective (or effective) temperature. 


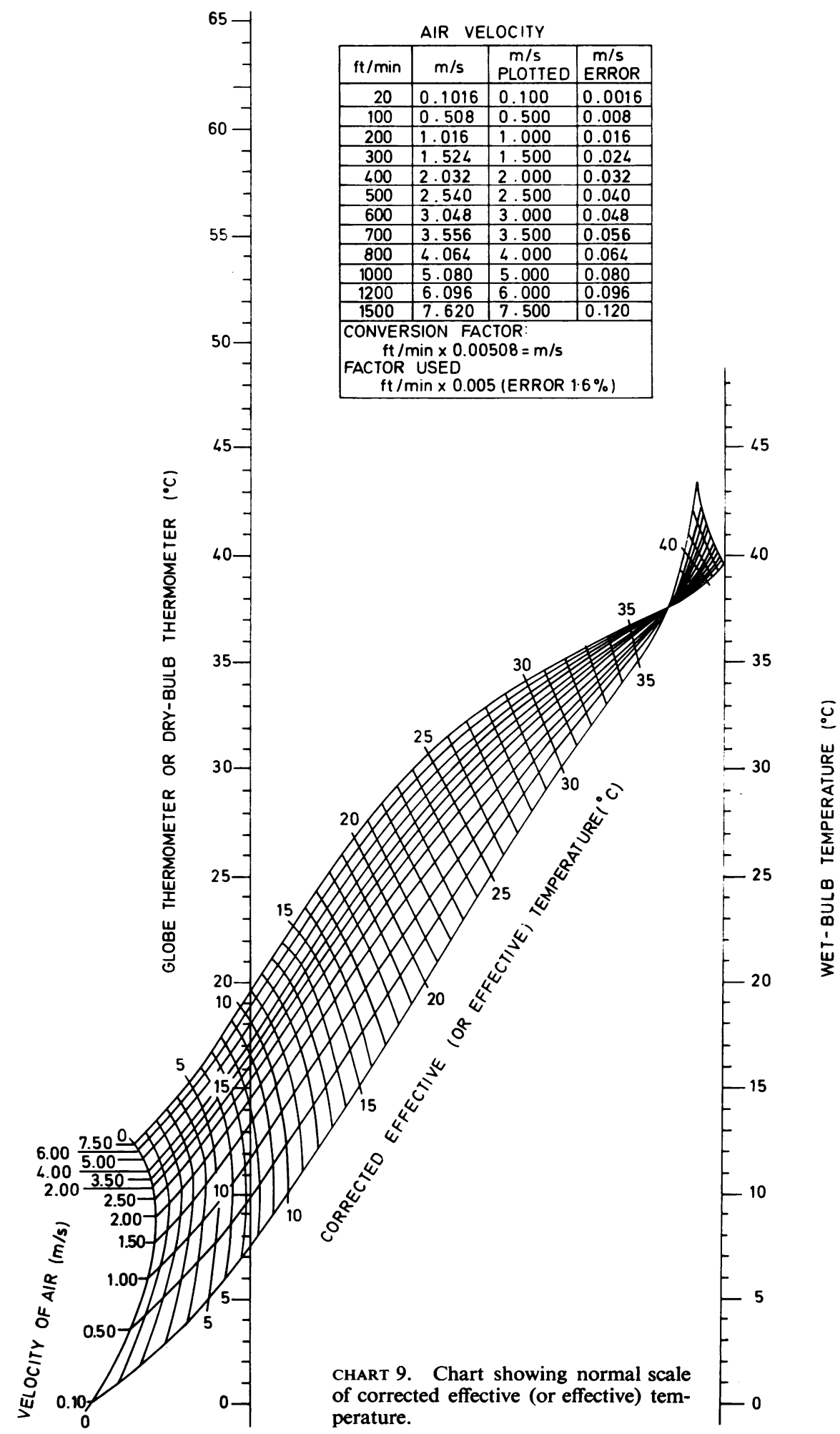




\begin{tabular}{|c|c|c|c|}
\hline \multicolumn{4}{|c|}{ AIR VELOCITY } \\
\hline $\mathrm{ft} / \mathrm{min}$ & $\mathrm{m} / \mathrm{s}$ & $\begin{array}{c}\mathrm{m} / \mathrm{s} \\
P L T E D\end{array}$ & $\begin{array}{l}\mathrm{m} / \mathrm{s} \\
\text { ERROR }\end{array}$ \\
\hline 20 & 0.1016 & 0.100 & 0.0016 \\
\hline 100 & 0.50 & 0.500 & 0.008 \\
\hline & & 1.0 & \\
\hline & & & \\
\hline & & & \\
\hline & & & \\
\hline 60 & 3.0 & & \\
\hline 700 & 3.556 & 3.500 & \\
\hline & 4.064 & 4.000 & 0.06 \\
\hline 1000 & 5.080 & $\frac{5.000}{6}$ & 0.08 \\
\hline 1200 & 6.096 & 6.000 & 0.09 \\
\hline & & 7.500 & 0.12 \\
\hline & & & \\
\hline
\end{tabular}

55 USED

$\mathrm{ft} / \mathrm{min} \times 0.005$ (ERROR $1.6 \%$ )

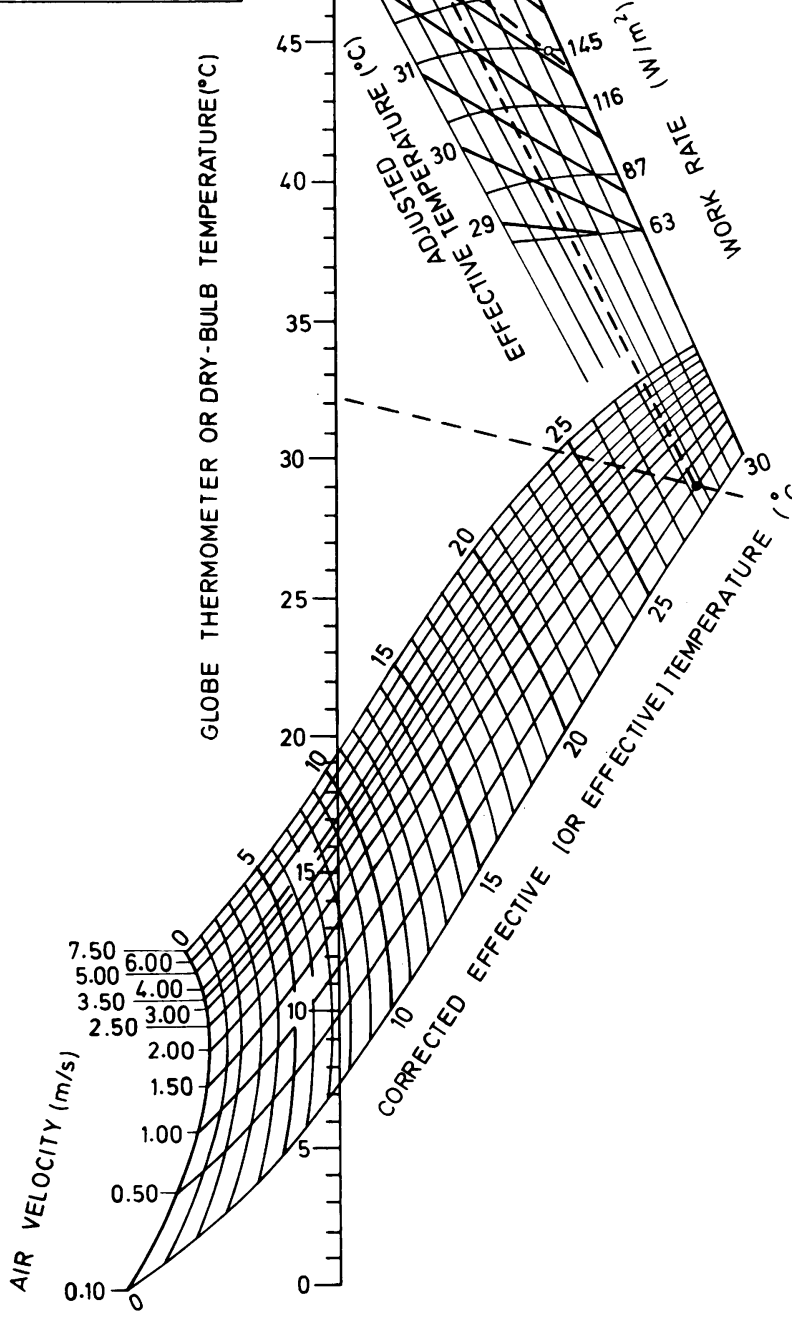

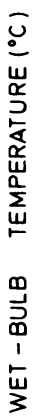

CHART 10. Normal scale of effective (or corrected effective) temperature with additional nomogram for including work rate. 


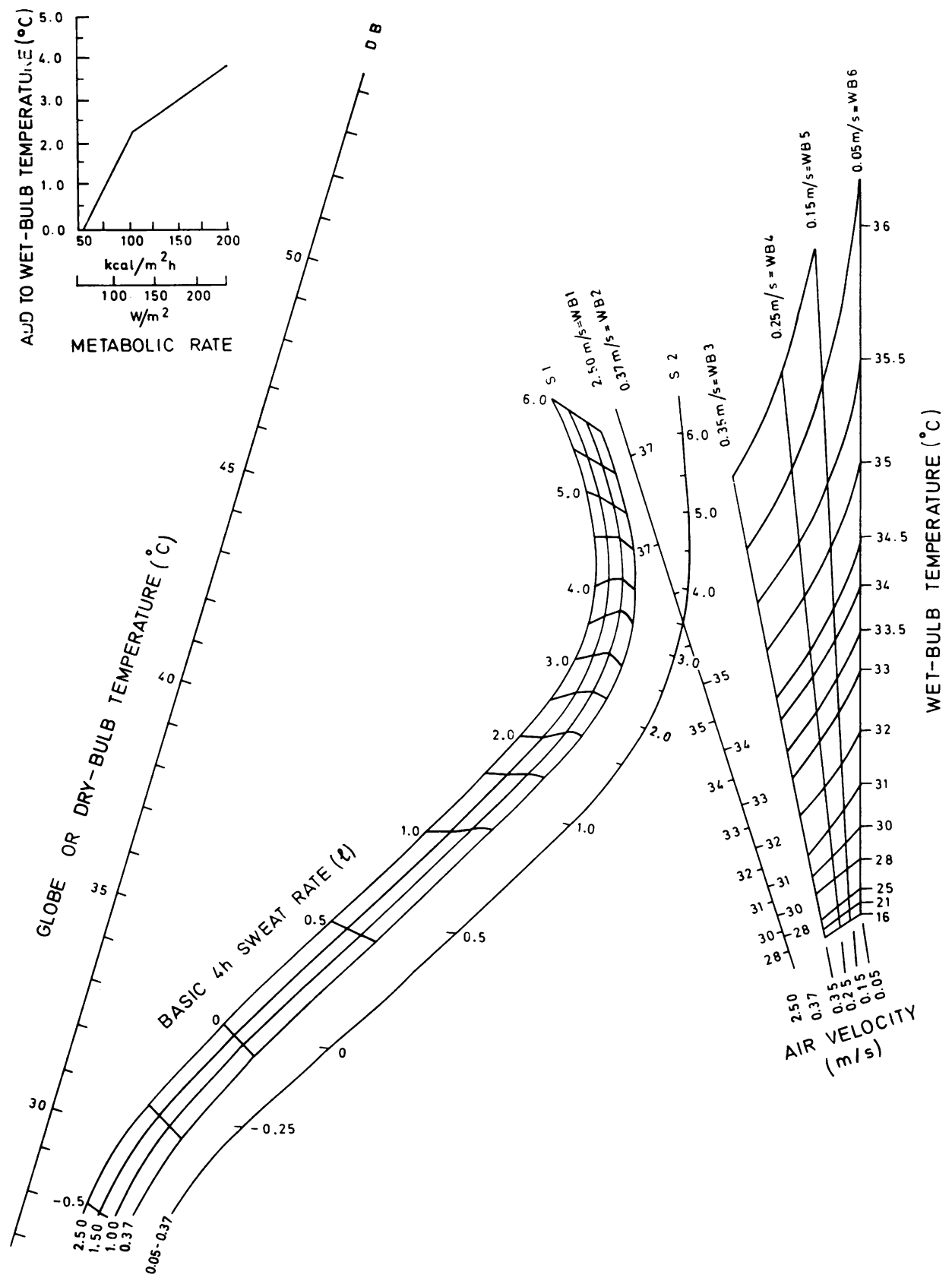

AIR VELOCITY $(\mathrm{m} / \mathrm{s})$

CHART 11. Nomogram for the prediction of the 'predicted 4-hour sweat rate' (P4SR). 
purpose-some points on the nomogram were observations for only one man, some represented the mean value for eight or more-exhaustive experiments at Singapore in the post-war years on tropically acclimatized naval ratings (Adam et al., 1952; Adam et al., 1955) showed that the nomogram was more accurate than effective temperature in the prediction of stressful physiological effects with tropically acclimatized young men as subjects under conditions when radiant heat was not a variable. Preliminary experiments incorporating radiant heat suggested that even the allowance made for radiant heat in the P4SR nomogram was surprisingly accurate (Ferres et al., 1954). Very few experiments on radiant heat had been done by the wartime team in England and these involved hastily assembled apparatus which fell far short of the more sophisticated equipment provided later at Singapore. The main conclusions of the London and Singapore studies have been summarized by Ellis (1953), and the Medical Research Council has published a compilation of all the physiological reports on this series of physiological experiments in London and Singapore (Macpherson, 1960).

Within the range of conditions and for the purpose for which it was designed we do not know any more accurate alternative to the well-tested P4SR nomogram for evaluating stressful conditions, but it is time that it was confirmed or modified by experiments designed to extend the ranges of air temperature, humidity, air speed, radiant heat, clothing, and work rates and to check its accuracy with the sophisticated instrumental, experimental, and computer techniques available today. Verification of the accuracy of the nomogram is also required when it is used for conditions of work in the field which may differ considerably from those with which it was designed to deal originally, as Wyndham (1970) recently suggested when he drew attention to certain anomalies in Report No. 298 (Macpherson, 1960) in a searching critique which has yet to be answered, so far as we are aware. The appendix explains the way in which the P4SR nomogram should be used.

McArdle's concept, using the sweat rate modified as he describes as an indicator of thermal stress, was probably the most significant contribution made by the RNPRC to this aspect of environmental medicine as a result of the second world war studies and paved the way for further developments such as the Heat Stress Index of Haines and Hatch (1952) and Belding and Hatch (1955) which has not, however, been evaluated by the RNPRC.

The aids which are used for the measurement of environmental warmth and its effects in the Royal Navy today include the wet-bulb globe thermometer index-the WBGT index-devised by the late Professor C. P. Yaglou (1956) and introduced into the United States Navy by Minard and his colleagues
(Belding, Minard, Wiebers, and Ross, 1956; Minard, Belding, and Kingston, 1957; Minard, Kingston, and Van Liew, 1960; Minard and O'Brien, 1964; Minard, 1961, 1964, 1965) and into the Royal Navy by Davies (1963) and Walters (1965, 1967). This index has the added advantage of simplicity: no charts are necessary, only the following simple calculation, valid for imperial or metric units:

WGBT index $=0.7$ wet-bulb temp. +0.2 globethermometer temp. $+\mathbf{0} \cdot \mathbf{1}$ dry-bulb temp.

The laboratory assessment of the relative accuracy of this index, the P4SR index and effective temperature over a comprehensive range of warm thermal environments to cover the widely divergent needs of industry, the civil population at large, and the military, has yet to be undertaken.

Direct-reading electrical instruments, a considerable advance on the prototype instrument referred to above (Walters, 1967), are now available which enable the WBGT index or the wet- and drybulb and globe temperatures and the air speed, and therefore the effective or corrected effective temperatures, to be ascertained at any given point with a minimum of delay. These new instruments are invaluable in the hands of those who know how to use them but are still in the developmental stage. Hygrometric Tables, Parts I, II, and III, are published by the Meteorological Office (1964a, b, c) for Stevenson Screen Readings, degrees $F$ and degrees C, and for Aspirated Psychrometer Readings, degrees Celsius, for those who prefer to use tables rather than charts for computing humidity values. In addition, the Institution of Heating and Ventilating Engineers has published two psychrometric charts graded in British and SI units respectively which engineers, in particular, may prefer to the psychrometric chart included in the supplement to the War Memorandum. Those who use globe thermometers of widely different diameters from the 6-inch globe on which Bedford based his equation and the mean-radiant temperature nomograms will find that Hey (1968) has provided a useful nomogram for calculating convective heat exchanges and meanradiant temperatures for black spheres and globe thermometers of different sizes. It is suggested that the charts shown here be used in conjunction with War Memorandum No. 17 until its revision or replacement.

\section{Comment}

The need to think in metric terminology has brought home the fact that the measurement of environmental warmth and its effects on man is still largely an empirical art rather than an exact science. It is likely to remain so for the foreseeable future, despite the determined efforts of biophysicists, mathematicians, engineers, and computer scientists who have 
turned their thoughts to this aspect of environmental medicine in recent years.

The direct conversion of Bedford's classical charts from imperial to metric units is a first attempt to make the current terminology and units used by the Royal Navy intelligible at the international level. Further conversion of instruments and methods will probably evolve naturally as the result of experience and practical application in the laboratory and the field; their careful reappraisal will be a formidable proposition involving a multidisciplinary approach but it is certainly overdue.

We are indebted to Dr. Brian McArdle, who read and commented on the penultimate and final drafts, to Chief Medical Technician (L) G. Nichols, of the Institute of Naval Medicine, Alverstoke, who redrew the charts, and to Mr. V. J. K. Rose and his colleagues of the Portsmouth Technical Illustrator Pool, H.M.S. Vernon, who reproduced the drawings.

\section{References}

Adam, J. M., Collins, J. A. G., Ellis, F. P., Irwin, J. O., Jack, J. W., John, R. T., Jones, R. M., Macpherson, R. K., and Weiner, J. S. (1955). Physiological responses to hot environments of young European men in the tropics, II and III. Med. Res. Coun. Lond. Rep. R.N.P. 55/831; published in Spec. Rep. Ser. med. Res. Coun. Lond. No. 298 [1960]. H.M.S.O., London.

- Ellis, F. P., Irwin, J. O., Thomson, M. L., and Weiner, J. S. (1952). Physiological responses to hot environments of young European men in the tropics, I. Med. Res. Coun. Lond. Rep. R.N.P. 52/721; published in Spec. Rep. Ser. med. Res. Coun. Lond. No. 298. [1960]. H.M.S.O., London.

Anderton, P., and Bigg, P. H. (1969). Changing to the Metric System. Conversion Factors, Symbols and Definitions, 3rd ed. (Ministry of Technology, National Physical Laboratory). H.M.S.O., London.

Bedford, T. (1944). Provisional Draft for Book of Reference on 'Environmental Warmth and Its Measurement'. Med. Res. Coun. Lond. Rep. R.N.P. 44/122.

(1945). Revised Draft for Book of Reference on 'Environmental Warmth and Its Measurement'. Med. Res. Coun. Lond. Rep. R.N.P. 45/198.

(1946). Environmental Warmth and its Measurement. War Memor. med. Res. Coun. Lond. No. 17. H.M.S.O., London.

(1964). Basic Principles of Ventilation and Heating, 2nd ed. H. K. Lewis, London.

Belding, H. S., and Hatch, T. F. (1955). Index for evaluating heat stress in terms of resulting physiological strains. Heating, Piping and Air Conditioning, 27, no. 8 (August), pp. 129-136. (ASRAE Journal Section).

-, Minard, D., Wiebers, J. E., and Ross, D. M. (1956). Heat stresses and strains of summer training at the Marine Corps recruit depot, Parris Island, South Carolina. Rep. No. 1 under Office of Naval Research Contract ONR 115-406 with the Department of Occupational Health, University of Pittsburgh.

British Standards Institution (1959). Conversion Factors and Tables. Part I. Basis of Tables. Conversion Factors. (B.S. 350: Part 1: 1959). London.

- (1962). Conversion Factors and Tables. Part 2. Detailed Conversion Tables (B.S. 350: Part 2: 1962).

_ (1967). Additional Tables for SI Conversions.
Metric and Inch Units. Supplement No. 1 (1967) to B.S. 350: Part 2: 1962 (PD 6203).

Davies, Wyndham R. (1963). Assessment of thermal conditions in H.M. Ships. Med. Res. Coun. Lond. Rep. R.N.P. 63/1036.

Ellis, F. P. (1945). First Report of the Habitability Mission to the Eastern Fleet: 1944. Med. Res. Coun. Lond. Rep. R.N.P. 45/202.

(1947a). The effect of environment on the health and efficiency of men in warships. M.D. thesis, Library of Medical School, University of Manchester.

(1947b). Effects of a tropical climate on men in warships. Brit. med. Bull., 5, 13.

- (1948). Environmental factors influencing health and efficiency in warships. Brit. med. J., 1, 587.

(1953). Tolerable and desirable levels of warmth in warm climates, with special reference to the requirements of men in the Royal Navy. Hunterian Lecture. Ann. roy. Coll. Surg. Engl., 13, 369.

(1969). Recent Advances in the Measurement of the Thermal Environment and its Effects on Naval Personnel. United Kingdom Paper No. 16, 9th Commonwealth Defence Conference on Clothing and General Stores, Kenya, 1969.

- (1970). Environmental Warmth and Its Measurement. Recent Advances. Med. Res. Coun. Lond. R.N.P. Rep. ES1.

—_, Ferres, H. M., Lind, A. R., and Newling, P. S. B. (1953) The upper tolerable levels of warmth for acclimatised European men working in the tropics. Med. Res. Coun. Lond. Rep. R.N.P. 53/759; published in Spec. Rep. Ser. med. Res. Coun. Lond. No. 298 [1960]. H.M.S.O., London.

Ferres, H. M., Fox, R. H., Jack, J. W., John, R. T., Lind, A. R., Macpherson, R. K., and Newling, P. S. B. (1954) Physiological responses to hot environments of young European men in the tropics. The effect of measuring the mean radiant temperature of the surroundings. Med. Res. Coun. Lond. Rep. R.N.P. 54/812; published in Spec. Rep. Ser. med. Res. Coun. Lond. No. 298 [1960]. H.M.S.O., London.

Haines, G. F. (Jr) and Hatch, T. (i952). Industrial heat exposures-evaluation and control. Heating and Ventilating, 49, November, pp. 93-104.

Her Majesty's Government (1972). Metrication. Secretary of State for Trade and Industry. Cmnd. 4880. H.M.S.O., London.

Hey, E. N. (1968). Small globe thermometers. J. sci. Instrum., series $2,1,955$.

McArdle, B., Dunham, W., Holling, H. E., Ladell, W. S. S., Scott, J. W., Thomson, M. L., and Weiner, J. S. (1947). The prediction of the effects of warm and hot environments. Med. Res. Coun. Lond. Rep. R.N.P. 47/391. Published in F. E. Smith (1955). Indices of Heat Stress. Med. Res. Coun. Lond. Memo No. 29; and Spec. Rep. Ser. med. Res. Coun. Lond. No. 298 [1960]. H.M.S.O., London.

Macpherson, R. K. (1960). Physiological Responses to Hot Environments. Spec. Rep. Ser. med. Res. Coun. Lond. No. 298. H.M.S.O., London.

Meteorological Office (1964a). Hygrometric Tables, Part III. Second Edition. Aspirated Psychrometer Readings, Degrees Celsius. Meterological Office 0.265c. H.M.S.O., London.

— - (1964b). Hygrometric Tables, Part II. Second Edition. Stevenson Screen Readings ${ }^{\circ} \mathrm{C}$. Meteorological Office 0.265b. H.M.S.O., London.

- (1964c). Hygrometric Tables, Part I. 6th ed. Stevenson Screen Readings ${ }^{\circ} \mathrm{F}$. Meteorological Office 0.265a. H.M.S.O., London.

Metrication Board (1970). Going Metric, Metric Units: An International System. H.M.S.O., London. 
Minard, D. (1961). Prevention of heat casualties in Marine Corps recruits, 1955-1960 with comparative incidence rates and climatic heat stresses in other training categories. Res. Rep. MR 005. 01-0001. Rep. No. 4. USN Medical Research Institute, Bethesda.

- (1964). Effective temperature scale and its modifications. Res. Rep. MR 005. 01-001. 01. Rep. No. 6. USN Medical Research Institute, Bethesda.

- (1965). Personal communication. 12 May.

—, Belding, H. S., and Kingston, J. R. (1957). Prevention of heat casualties. J. Amer. med. Ass., 165, 1813-1818.

-_, Kingston, J. R., and Van Liew, H. D. (1960). Heat stress in working spaces of an aircraft carrier. Res. Rep. MR 005. 01-0001. 01 Rep. No. 3. USN Medical Research Institute, Bethesda.

- and O'Brien, R. L. (1964). Heat casualties in the Navy and Marine Corps 1959-1962 with appendices on the field use of the wet bulb-globe temperature index. Res. Rep. MR 005.01-0001. 01 Rep. No. 7. USN Medical Research Institute, Bethesda.

National Physical Laboratory (1970). S.I. The International System of Units. H.M.S.O., London.

Royal Society (1968). Conference of Editors. Metrication in Scientific Journals. London.

-_ (1969). Symbols, Signs, and Abbreviations Recommended for British Scientific Publications. London.

Smith, F. E. (1952). Effective temperature as an index of physiological stress. Med. Res. Coun. Lond. Rep. R.N.P. 53/728.

(1955). Indices of Heat Stress. Med. Res. Coun. Lond. Memo No. 29. H.M.S.O., London.

Walters, J. D. (1965). Human endurance in intolerable climates. J. Roy. nav. med. Serv., 51, 208-220 and Discussion 220-221.

_ (1967). A field assessment of a prototype meter for measuring the wet-bulb globe-thermometer index (WBGT index). Med. Res. Coun. Lond. Rep. R.N.P. 67/1089.

World Health Organization, Technical Report Series No. 412 (1969). Health Factors Involved in Working under Conditions of Heat Stress. Report of a WHO Scientific Group. World Health Organization, Geneva.

Wyndham, C. H. (1970). The P4SR index-Some anomalies in the Medical Research Council's Special Report No. 298. Environ. Res., 3, 381-390.

Yaglou, C. P. and others (1956). Habitability studies in climatic extremes. Annual Report No. 9 to Commission on Environmental Hygiene, United States Armed Forces Epidemiological Board. Quoted by Minard (1961).

Some of the reports quoted may not be available.

Application may be made to The Assistant Secretary, Royal Naval Personnel Research Committee, Room 1518, Ministry of Defence (Navy), Empress State Building, Lillie Road, London, SW6 1TR.

\section{APPENDIX}

\section{Calculation of the P4SR index}

The nomogram required for the derivation of the P4SR index is included as Chart 11. The stages in the calculation are:

Stage 1-Calculation of 'modified wet-bulb temperature'

The wet-bulb temperature measured in a given environment will require modification if:

(a) the globe-thermometer temperature differs from the dry-bulb temperature. In this case the correction to be added to the observed wet-bulb temperature is given by the equation:

Correction $=0.4$ (GT-DB)

(b) the energy expenditure exceeds $63 \mathrm{~W} / \mathrm{m}^{2}$ (the metabolic rate of men seated in chairs). In this case an amount determined from the small insert curve in the top left-hand corner of Chart 11 is added to the wet-bulb temperature. Where the energy expenditure is not known then the following corrections are applied:

\begin{tabular}{lcc}
\hline Level of activity & $\begin{array}{c}\text { Approximate average } \\
\text { energy expenditure } \\
\left(\mathrm{W} / \mathrm{m}^{2}\right)\end{array}$ & $\begin{array}{c}\text { Add to } \\
\text { wet-bulb temp. } \\
\left({ }^{\circ} \mathrm{C}\right)\end{array}$ \\
\hline Sedentary & 76 & $0 \cdot 6$ \\
Light & 116 & $2 \cdot 2$ \\
Moderate & 192 & $3 \cdot 3$ \\
Heavy & 262 & $4 \cdot 2$ \\
\hline
\end{tabular}

(c) the men are wearing clothing other than shorts. In the case of cotton drill overalls worn over shorts the increment is $1.0^{\circ} \mathrm{C}$ added to the wet-bulb temperature, and the amount for other clothing assemblies may be calculated proportionately.

Example Suppose a subject is required to work in an environment at an energy expenditure of 116 $\mathrm{W} / \mathrm{m}^{2}$ wearing overalls over shorts and where the observed climatic variables are:
wet-bulb temperature
$29^{\circ} \mathrm{C}$
dry-bulb temperature
$43.0^{\circ} \mathrm{C}$
globe-thermometer temperature $46 \cdot 0^{\circ} \mathrm{C}$
air movement
$0.25 \mathrm{~m} / \mathrm{s}$

The corrections to be made to the wet-bulb temperature are:

1. for globe-thermometer/dry-bulb temperature difference $(0 \cdot 4(46 \cdot 0-43 \cdot 0))$

2. for level of energy (from inset curve)

3. for clothing (overalls over shorts)

$=1 \cdot 0$

Total $=4 \cdot 4$

The modified wet-bulb temperature is therefore:

$$
29 \cdot 0+4 \cdot 4=33 \cdot 4^{\circ} \mathrm{C}
$$

\section{Stage 2-Calculation of B4SR (basic 4-hour sweat rate)}

The basic 4-hour sweat rate is required for the final determination of P4SR but, except in the single case of men sitting in shorts, when the B4SR is equal to the P4SR, it is without physiological significance.

Using Chart 11, a line is drawn between the point on the left-hand scale corresponding to the observed globe or dry-bulb temperature, according to whether or not the globe-thermometer temperature is known, and the point on the wet-bulb scale corresponding to the modified wet-bulb temperature. There are six wet-bulb scales (WB1 to WB6) on the right-hand 
side of the Chart related to a range of air velocities from 0.05 to $2.50 \mathrm{~m} / \mathrm{s}$, and the scale appropriate to the observed air velocity must be chosen. The B4SR value may be read from the point where this line intersects the basic 4-hour sweat rate line appropriate to the observed air velocity.

In the example above, the B4SR would be 3.2 litres (using line WB4 and the 0.05 and $0.37 \mathrm{~m} / \mathrm{s}$ B4SR line). Had the observed air velocity been 2.5 $\mathrm{m} / \mathrm{s}$, the B4SR would have been $2 \cdot 8$ litres (using line WB1 and the $2.50 \mathrm{~m} / \mathrm{s}$ B4SR line).

\section{Stage 3-Calculation of P4SR}

1. For men sitting at rest in shorts

In this particular case the B4SR is equal to the P4SR. In every other case an allowance must be made for the effect of energy expenditure and clothing worn.

2. For men working in shorts

The P4SR is calculated from the equation:

$\mathrm{P} 4 \mathrm{SR}=\mathrm{B} 4 \mathrm{SR}+0.012(\mathrm{M}-63)$ where $\mathbf{M}$ is the metabolic rate in $\mathrm{W} / \mathrm{m}^{2}$. If this value is not known the approximations given above may be used and substituted for $M$.

3. For men sitting at rest wearing overalls over shorts For this situation it is only necessary to add 0.25 to the B4SR.

4. For men working in overalls over shorts The P4SR is calculated from the equation:

$\mathrm{P} 4 \mathrm{SR}=\mathrm{B} 4 \mathrm{SR}+0.25+0.017(\mathrm{M}-63)$

where $M$ is the level of energy expenditure, or where this is not known, a value taken from the approximations given above.

In the example above, the calculation of the P4SR would be completed by solving the equation:

P4SR $=3 \cdot 2+0.25+0.017(116-63)=4.35$ litres.

Had the air velocity been $2.4 \mathrm{~m} / \mathrm{s}$ then the P4SR would have been 3.97 litres.

Received for publication September 14, 1971. 